\title{
Larvae of the water scavenger beetle, Hydrophilus acuminatus (Coleoptera: Hydrophilidae) are specialist predators of snails
}

\author{
Toshio INODA ${ }^{1}$, Yuta INODA ${ }^{1}$ and June KathyleEn RULLAN ${ }^{2}$ \\ ${ }^{1}$ Shibamata 5-17-10, Katsushika, Tokyo 125-0052, Japan; e-mail: inoda@kxb.biglobe.ne.jp \\ ${ }^{2}$ University of the Philippines, Manila, Philippines; e-mail: kathy_rullan@yahoo.com.ph
}

Key words. Coleoptera, Hydrophilidae, Hydrophilus acuminatus, feeding preferences, snail specialist

\begin{abstract}
Hydrophilus acuminatus larvae are known to feed on aquatic prey. However, there is no quantitative study of their feeding habits. In order to determine the feeding preferences and essential prey of larvae of H. acuminatus, both field and laboratory experiments were carried out. Among the five potential species of prey, Austropeplea ollula (Mollusca: Lymnaeidae), Physa acuta (Mollusca: Physidae), Asellus hilgendorf (Crustacea: Asellidae), Palaemon paucidens (Crustacea: Palaemonidae) and larvae of Propsilocerus akamusi (Insecta: Chironomidae), the first instar larvae of H. acuminatus strongly prefered the Austropeplea and Physa snails in both cafeteria and single-prey species experiments. Larvae that were provided with only snails also successfully developed into second instar larvae, while larvae fed Palaemon, Propsilocerus larvae or Asellus died during the first instar. In addition, the size of adult $H$. acuminatus reared from first-instar larvae and fed only snails during their entire development was not different from that of adult $H$. acuminatus collected in the field. This indicates that even though the larvae of H. acuminatus can feed on several kinds of invertebrates, they strongly prefer snails and without them cannot complete their development.
\end{abstract}

\section{INTRODUCTION}

Predacious aquatic insects are a diverse group and the top predators in fishless water habitats. Larvae and adults of some species of diving beetles (Dytiscidae), for example, are regarded as effective predators of mosquito larvae (Bay, 1974; Berman et al., 2000; Lundkvist et al., 2003), other insect larvae, amphibian larvae, isopods and fish fry (Blunck, 1923; Balduf, 1935; Wesenberg-Lund, 1943; Jeffries, 1988; Johansson \& Nilsson, 1992; Inoda \& Kamimura, 2004; Inoda et al., 2009).

Although predatory aquatic insects have been studied for decades, the feeding ecology and behaviour of many taxa are relatively poorly known. In the past, most predatory aquatic insects in standing water were thought to be generalists (Batzer \& Wissinger, 1996; Cummins, 1973; Bay, 1974). However, recent laboratory experiments and field studies have shown that they are often specialists rather than generalists (Klečka \& Boukal, 2012).

Some predators are known to have adaptations for handling certain types of prey, such as asymmetric feeding structures. For example, some snail-eating specialists have a conspicuous, one-sided asymmetry in their feeding apparatus (Shoup, 1968; Snyder \& Snyder, 1969; Ng \& Tan, 1985; Hoso et al., 2007). Since snail shells are mainly dextral (i.e., with right-handed coiling of the shell) regardless of habitat (Vermeij, 1975), to specialize on dextral snails would be selectively advantageous for predators of snails (Shoup, 1968; Snyder \& Snyder, 1969; Ng \& Tan, 1985; Inoda et al., 2003; Shigemiya, 2003; Hoso et al., 2007). Asymmetrical mandibles that may indicate a specialized feeding apparatus are common in the larvae of various groups of Hydrophilidae, e.g., Laccobius, Berosus and some Acidocerinae (Archangelsky, 1997; Minoshima \&
Hayashi, 2011). While the diet of most of these groups is poorly known, the larvae of Hydrophilus are reported to feed on freshwater snails, insect larvae, amphibian larvae, isopods and fish (e.g., Miall, 1895; Kawamura, 1918; Wilson, 1923; Bøwing \& Henriksen, 1938; Hosoi, 1939; Tsuda, 1983; Archangelsky, 1997; Inoda et al., 2003). Under laboratory conditions, the larva of Hydrophilus acuminatus feed on Caenestheriella gifuensis, Tubifex tubifex, Carassius auratus (Tsuda, 1983) and viviparid snails (Hosoi, 1939). These observations suggest that Hydrophilus species are generalist predators.

On the other hand, Inoda et al. (2003) report that the asymmetric mandibles of $H$. acuminatus are more suitable for feeding on right-handed (Austropeplea ollula) than left-handed snails (Physa acuta). As there is no quantitative analysis of the eating of snails by $H$. acuminatus, the present study provides a brief survey of the acceptability of the potential prey in a natural habitat of $H$. acuminatus and the results of laboratory experiments on the prey preferences, essential prey and ability the first instar larvae to complete their development when fed different types of prey.

\section{MATERIAL AND METHODS}

\section{Field observations and identification of potential prey}

To identify the potential prey of $H$. acuminatus larvae, an aquatic community in an irrigation ditch of a rice paddy in Tochigi Prefecture (Nasu), Japan was surveyed. Larvae of H. acuminatus were also repeatedly found at this site during this study. The ditch was $15 \times 1 \mathrm{~m}$, the depth of the static water $30-50 \mathrm{~cm}$ and had a muddy bottom, in which grew two species of water plants, Cabomba caroliniana and Sagittaria trifolia. Cabomba caroliniana was the most abundant and dominant plant. This community was surveyed using 60 quadrates $(50 \times 50 \mathrm{~cm})$ in June of 2005, 
2007 and 2009 and the samples from all quadrates were subsequently pooled each year. The animals were collected using a Dtype net $(45 \times 40 \times 40 \mathrm{~cm}$ with a mesh size of $0.8 \mathrm{~mm})$ by means of a single sweep through the water column and across the bottom as described in Inoda et al., 2009. The animals were counted and identified using the following references: aquatic insects (Tsuda, 1983; Mori \& Kitayama, 2002), amphibians (Uchiyama et al., 2002), fish (Nakabo, 2000) and other benthic animals (Ueno, 1973).

Potential prey were kept in an aquarium $(74 \times 39 \times 40 \mathrm{~cm}$; water depth $20 \mathrm{~cm}$ ) until the experiment started. The mud from the beetles' habitat and some aquatic plants, such as giant elodea (Elodea densa), fanwort (Cabomba caroliniana) and Japanese parsley (Oenanthe javanica), were collected and placed in the same aquarium. The plants, giant elodea, fanwort and Japanese parsley, were planted with vegetation cover rate (VCR; BraunBlanquet, 1964) of $35 \%, 35 \%$ and $10 \%$, respectively. The VCR for each species in the aquarium was measured as follows. The aquarium was photographed from above with a digital camera (Nikon, CoolPi $\times 990$, Tokyo, Japan) and the VCR of each plant species and the open spaces were measured from pixel counts using Photoshop 6.0 (Adobe systems); see (Inoda, 2011) for details. Dechlorinated tap water was supplied every $6 \mathrm{~h}$ to keep the water clean (Inoda \& Kamimura, 2004).

\section{Breeding of larvae}

First instar larvae of $H$. acuminatus (c.a., $20 \mathrm{~mm}$ body length) were collected from June to July of 2009 and used in the experiments 1-2 days after hatching. The larvae were not provided with food before the experiments. To obtain the larvae, adult $H$. acuminatus were collected in Tochigi Prefecture (Nasu), Japan. Five pairs were kept in an outdoor aquarium $(74 \times 39 \times 40 \mathrm{~cm}$, with a $20 \mathrm{~cm}$ water column) following the method used by Inoda et al. (2003). During oviposition, females laid egg cases each containing approximately 30 eggs. The egg cases were transferred to an artificial breeding system (Inoda et al., 2003; Inoda \& Kamimura, 2004) and kept there until the larvae hatched.

\section{Feeding experiments}

We conducted a series of individual-level feeding experiments using first-instar larvae of $H$. acuminatus. All these experiments were carried out in small aquaria $(12 \times 8 \times 8 \mathrm{~cm}$; water depth 6 $\mathrm{cm}$, water temperature $25-28^{\circ} \mathrm{C}$ ) placed outdoors. All these experiments were run for eight hours between 22:00 and 6:00 (June 9-16, 2009).

\section{Experiment 1: Screening of potential prey and predators of the first instar larvae}

To determine the potential prey to be used in subsequent experiments, we placed one first-instar larva of $H$. acuminatus and one individual animal of each potential prey species in each aquarium $(n=3)$. At the end of each trial we assessed whether predation had occurred, and if so, who ate whom.

\section{Experiment 2: Prey selectivity in cafeteria experiment}

After conducting the screening test, five species were selected as potential prey: Palaemon paucidens, Propsilocerus akamusi larvae, Asellus hilgendorfi, Austropeplea ollula and Physa acuta To investigate the feeding preferences of $H$. acuminatus in detail, one beetle larva and three specimens of each potential prey (i.e., one beetle larva with 15 prey items) were placed together in an aquarium. The number of prey consumed and number of beetle larvae that fed on prey were counted at the end of each trial. Percentage predation was calculated as follows:

Percentage predation $(\%)=100 \times($ Number of beetle larvae which fed on at least one prey item)/ (Total number of beetle larvae).
In addition to percentage predation, we used Manly's alpha preference index for constant prey populations (Chesson, 1978; Krebs, 1989) to calculate the preference of beetle larvae for different species of prey:

$\alpha_{i}=\left(r_{i} / n_{i}\right) /\left[1 / \sum_{i=1}^{m}\left(r_{i} / n_{i}\right)\right]$

where $\alpha_{\mathrm{i}}$ is the preference index for prey type $i, r_{i}$ is the proportion of prey item $i, n_{i}$ is the proportion of prey item $i$ in the environment, and $m$ is the total number of types of prey (in this case, $m=5$ prey species). If $\alpha_{i}>1 / m$, prey species $i$ is preferred. Conversely, $\alpha_{i}<1 / m$ indicates avoidance of prey species $i$. The number of replicates was 30 and beetle larvae were not used repeatedly.

\section{Experiment 3: Single-prey predation}

One beetle larva and three individual specimens of a singleprey (i.e., one beetle larva versus three prey individuals) were placed together in an aquarium in this experiment. A total of 179 beetle larvae were used (38 Palaemon paucidens, 39 Propsilocerus akamusi larvae, 33 Asellus hilgendorfi, 34 Austropeplea ollula and 35 Physa acuta). Neither predators nor prey individuals were used repeatedly. The number of beetle larvae that consumed prey was counted at the end of the experiment and the percentage predation calculated as outlined above.

\section{Experiment 4: Essential prey and survival of the larvae}

To investigate the percentage survival of the first instar larvae when provided with a single species of prey, one beetle larva and three individual specimens of the same species of prey were placed in the aquarium $(12 \times 8 \times 8 \mathrm{~cm}$; water depth $6 \mathrm{~cm})$. A total of 113 beetle larvae were used in this experiment (23 Palaemon paucidens, 22 Propsilocerus akamusi larvae, 15 Asellus hilgendorfi, 24 Austropeplea ollula and 29 Physa acuta) and they were not used repeatedly. The number of larvae that developed into the second instar was counted and the percentage survival calculated as follows:

Percentage survival $(\%)=100 \times($ Number of larvae that developed into the second instar) / (Total number of larvae).

Prey was provided everyday to keep the number of each type of prey constant. Water in each aquarium was changed with aged tap water daily and the debris of prey carcasses was also removed.

To supplement the feeding experiments described above, we measured body length and width of adult beetles reared from the first instar larvae fed on Austropeplea or Physa in order to clarify the nutritional suitability of snails for the development of H. acuminatus. First, we placed two aquaria $(75 \times 40 \times 35 \mathrm{~cm})$ containing water to a depth of $10-15 \mathrm{~cm}$ outdoors. Each aquarium contained H. acuminatus larvae and Austropeplea or Physa as prey. The aquaria were covered with $3-\mathrm{mm}$ mesh plastic lids to reduce the intensity of direct sunlight (corresponding to a $50 \%$ reduction in light intensity) and prevent larvae from escaping. The aquatic plants, giant elodea, fanwort and Japanese parsley, with VCRs of $35 \%, 35 \%$ and $10 \%$, respectively were also placed in the aquaria to provide resting places. Eaten prey were regularly replaced to maintain constant numbers of prey in each aquarium. Dechlorinated tap water was supplied every six hours (Inoda \& Kamimura, 2004). Third instar larvae, which stopped feeding prior to pupation (body length approximately $60 \mathrm{~mm}$ ), were transferred to plastic containers filled with moist peat moss $(11 \times 8 \times 7$ $\mathrm{cm})$ and kept at $20-25^{\circ} \mathrm{C}$ until adult emergence. Body size of the adult beetles was measured and compared with that of adults collected in the wild. 
TABLE 1. List of candidate prey species found in an irrigation ditch of a rice paddy in Tochigi Prefecture, Japan in June of 2005, 2007, and 2009. $N=$ total number of individuals found.

\begin{tabular}{|c|c|c|c|c|c|c|c|}
\hline \multirow{2}{*}{ Class } & \multirow{2}{*}{ Order } & \multirow{2}{*}{ Family } & \multirow{2}{*}{ Species } & \multirow{2}{*}{$\begin{array}{c}\text { Body size } \\
(\mathrm{mm})\end{array}$} & \multicolumn{3}{|c|}{$N$} \\
\hline & & & & & 2005 & 2007 & 2009 \\
\hline Actinopterygii & Cypriniformes & Cobitidae & Misgurnus anguillicaudatus & $40-45$ & 6 & 8 & 9 \\
\hline Amphibia & Caudata & Salamandridae & Cynops pyrrhogaster & $80-100$ & 10 & 3 & 5 \\
\hline Gastropoda & Pulmonata & Lymnaeidae & Austropeplea ollula & $* 5-7$ & 8 & 18 & 7 \\
\hline Gastropoda & Pulmonata & Physidae & Physa acuta & $* 5-7$ & 13 & 8 & 21 \\
\hline Insecta & Coleoptera & Dytiscidae & Cybister brevis & $20-23(15-20)$ & $2(2)$ & $1(1)$ & $0(1)$ \\
\hline Insecta & Coleoptera & Dytiscidae & Cybister chinensis & $30-35$ & (1) & 0 & 0 \\
\hline Insecta & Coleoptera & Dytiscidae & Hydaticus bowringii & $13-14$ & 4 & 1 & 2 \\
\hline Insecta & Coleoptera & Dytiscidae & Rhantus suturalis & $11-12$ & 5 & 8 & 7 \\
\hline Insecta & Coleoptera & Hydrophilidae & Hydrophilus acuminatus & $35-39(19-21)$ & $5(2)$ & $5(1)$ & $2(4)$ \\
\hline Insecta & Hemiptera & Nepidae & Ranatra chinensis & $41-45$ & 3 & 1 & 1 \\
\hline Insecta & Hemiptera & Belostomatidae & Diplonychus japonicus & $18-20$ & 9 & 8 & 11 \\
\hline Insecta & Hemiptera & Belostomatidae & Kirkaldyia deyrolli & $12-17$ & (2) & (1) & (0) \\
\hline Insecta & Diptera & Chironomidae & Propsilocerus akamusi & 10 & 15 & 8 & 21 \\
\hline Insecta & Odonata & Libellulidae & $* *$ Dragonflies & $15-20$ & $(23)$ & (10) & (8) \\
\hline Malacostraca & Isopoda & Asellidae & Asellus hilgendorfi & $5-8$ & 71 & 45 & 82 \\
\hline Malacostraca & Isopoda & Palaemonidae & Palaemon paucidens & $5-8$ & 8 & 4 & 6 \\
\hline Malacostraca & Decapoda & Cambaridae & Procambarus clarkii & $25-30$ & 24 & 35 & 15 \\
\hline
\end{tabular}

Parentheses indicate larvae; ${ }^{*}$ - shell length; ${ }^{* *}$ - unidentified species.

\section{Data analysis}

Fisher's exact test was first conducted to assess the differences in percentage predation and percentage survival. If there was a statistical difference and all data were non-zero, Ryan's multiple comparisons for proportions (Ryan, 1960) were used to determine differences between groups. Two sets of binary data, feed/not feed and survive/die, were used in the analysis.

Differences in the body sizes of the beetles reared on a diet of Austropeplea ollula or Physa acuta and collected in the wild, were analyzed using Tukey's multiple comparison test.

Statistical analyses were carried out using R software, version 3.0.1 (R Development Core Team, 2013). Significance level was set at $\mathrm{P}=0.05$ in all tests.

\section{RESULTS}

Nineteen taxa were collected at the field site (Table 1). The isopod Asellus hilgendorfi was the most abundant taxon uniformly present throughout the habitat and in different years (data not shown), followed by the crayfish Procambarus clarkii, chironomid Propsilocerus akamusi and two gastropod species, Austropeplea ollula and Physa acuta. In the first experiment, we established that only five of these taxa, Palaemon, Propsilocerus larvae, Asellus and the two species of snails (Austropeplea and Physa), were eaten by first-instar larvae of $H$. acuminatus and thus used as potential prey in subsequent experiments (Table 2). Three of the five species of potential prey, Palaemon, Propsilocerus larvae and Asellus, were not eaten by $H$. acuminatus larvae in the cafeteria experiment (Experiment 2). On the other hand, $21(70 \%)$ and $17(57 \%)$ of 30 beetle larvae fed on Austropeplea and Physa, respectively. Fisher's exact test revealed a marked differences in the feeding preferences of $H$. acuminatus larvae for these five species of prey $(\mathrm{P}<0.001)$. Manly's alphas for the three species of prey that were ignored prey were zero, while those for the snails (Austropeplea and Physa) were 0.58 and 0.43, respectively, indicating that both of these snails were preferred prey.

When beetle larvae were provided with a single species of prey (Experiment 3) they consumed the other three potential species of prey: Palaemon ( 8 of 38 beetle larvae, percentage predation: 21\%), Propsilocerus larvae (17 of 39 beetle larvae, 44\%) and Asellus (13 of 33 beetle larvae, $39 \%$ ). Nevertheless, the larvae always fed on the two

TABLE 2. Screening of prey candidates of first-instar H. acuminatus larvae $(\mathrm{n}=3)$. $N_{\text {prey }}=$ number of individuals eaten by $H$. acuminatus larvae (prey link); $N_{\text {pred }}=$ number of $H$. acuminatus larvae eaten by the prey candidate (predation link).

\begin{tabular}{cccc}
\hline Prey candidate species & Body length [mm] & $N_{\text {prey }}$ & $N_{\text {pred }}$ \\
\hline Misgurnus anguillicaudatus & $40-45$ & 0 & 2 \\
Cynops pyrrhogaster & $80-100$ & 0 & 1 \\
Austropeplea ollula & $* 5-7$ & 3 & 0 \\
Physa acuta & $* 5-7$ & 3 & 0 \\
Cybister brevis & $20-23$ & 0 & 0 \\
Cybister brevis larvae & $15-20$ & 0 & 3 \\
Cybister chinensis larvae & $30-35$ & 0 & 3 \\
Hydaticus bowringii & $13-14$ & 0 & 0 \\
Rhantus suturalis & $11-12$ & 0 & 0 \\
Hydrophilus acuminatus & $35-39$ & 0 & 0 \\
Hydrophilus acuminatus larvae & $19-21$ & 0 & 0 \\
Ranatra chinensis & $41-45$ & 0 & 1 \\
Diplonychus japonicus & $18-20$ & 0 & 2 \\
Kirkaldyia deyrolli larvae & $12-17$ & 0 & 3 \\
Propsilocerus akamusi larvae & 10 & 1 & 0 \\
Asellus hilgendorfi & $5-8$ & 1 & 0 \\
Palaemon paucidens & $5-8$ & 1 & 0 \\
Procambarus clarkii & $25-30$ & 0 & 1 \\
**Dragonfly larvae & $15-20$ & 0 & 1 \\
\hline Body
\end{tabular}

Body length indicate animal size used in the experiments; * shell length; ${ }^{* *}$ - unidentified species. 


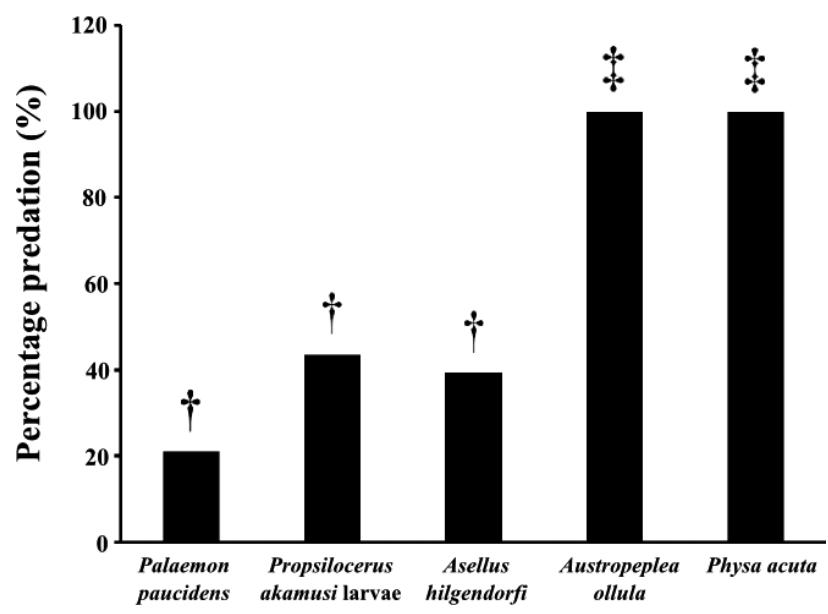

Fig. 1. Percentage predation by larvae of $H$. acuminatus provided with single species of prey. Columns with different symbols indicate significant differences $(\mathrm{P}<0.05)$.

snail species: Austropeplea (34 of 34 beetle larvae) and Physa (35 of 35 beetle larvae) (Fig. 1). This again indicates a stronger preference for feeding on snails than the other species ( $\mathrm{P}<0.05$, Ryan's multiple comparisons). When only Palaemon, Propsilocerus larvae or Asellus were provided as prey for the larvae of $H$. acuminatus, all of the larvae $(23,22$ and 15, respectively) died during the first instar. On the other hand, the larvae provided with each of the snail species, Austropeplea and Physa, developed into the second instar. The percentage survival of the first instar larvae was $96 \%$ (23 of 24 beetle larvae survived) when provided with Austropeplea and 97\% (28 of 29 beetle larvae survived) when provided with Physa. The survivorship of the larvae provided with each of the five different types of prey differed greatly ( $\mathrm{P}<0.001$, Fisher's exact test). As shown in Table 3 , there was no significant difference in the body size (body length and width) of $H$. acuminatus adults reared from larvae fed only snails (Austropeplea or Physa) and those collected in the field ( $\mathrm{P}>0.64$, Tukey's multiple comparison t-test). In addition to body size, 100\% completed their development. This indicates that snails provide sufficient nutrition for the growth of beetle larvae.

\section{DISCUSSION}

Top invertebrate predators substantially affect the biomass, species composition and diversity of fishless pond ecosystems (Turner \& Chislock, 2007; Cobbaert et al., 2010). Predators can reduce the numbers of some species of prey. Snail biomass in fishless marshes and ponds is influenced by direct predation by dragonfly nymphs (Turner $\&$ Chislock, 2007). In the present study, the larvae of $H$. acuminatus showed a marked preference for feeding on snails, suggesting that larvae may directly affect snail biomass in their habitats. Adult beetles reared from the firstinstar larvae on a diet consisting only of snails were of normal size, indicating that snails are an important prey that can support the complete development of Hydrophilus larvae. As we used only first-instar larvae in the feeding experiments, a similar study using all instars should be
TABLE 3. Comparison of the body size of bred and wild-caught H. acuminatus adults.

\begin{tabular}{|c|c|c|c|c|c|}
\hline & & Food & $\begin{array}{l}\text { Body } \\
\text { length } \\
{[\mathrm{mm}]}\end{array}$ & $\begin{array}{l}\text { Body } \\
\text { width } \\
{[\mathrm{mm}]}\end{array}$ & Statistics \\
\hline & Bred (18) & stropep & $39.2 \pm 1.6$ & $18.8 \pm 0.8$ & \\
\hline Female & Bred (10) & Physa & $39.4 \pm 1.0$ & $19.0 \pm 0.7$ & NS \\
\hline & Wild (10) & - & $39.3 \pm 3.2$ & $19.2 \pm 2.2$ & \\
\hline & Bred (20) & stropep & $36.9 \pm 2.0$ & $17.6 \pm 1.0$ & \\
\hline Male & Bred (10) & Physa & $36.5 \pm 2.3$ & $17.5 \pm 1.1$ & NS \\
\hline & Wild (10) & - & $37.3 \pm 2.2$ & $17.7 \pm 1.3$ & \\
\hline
\end{tabular}

Number in parentheses indicates sample size. Values are mean \pm SD. NS - non-significant difference based on a Tukey's multiple comparison test.

conducted in order to fully quantify their ability to control snail populations.

Many reports have suggested that Hydrophilus larvae can feed on many types of prey (Kawamura, 1918; Wilson, 1923; Hosoi, 1939; Tsuda, 1983; Inoda et al., 2003), even snakes (Mori \& Ohba, 2004). However, there is no information on what cues larvae use to detect food and which species of prey they need to complete their development. The present study experimentally demonstrates that $H$. acuminatus larvae are specialist predators of snails. It is not clear why the larvae of this species in this study also fed on prey on which they were not able to successfully complete their development. In the case of diving beetles, Dytiscus verticalis (Coleoptera: Dytiscidae), the larvae use mechanical stimuli or some chemical cues instead of visual cues to find prey (Formanowicz, 1987). The larvae of Dytiscus sharpi sharpi also respond to the scent of prey when hunting (Inoda, 2012), e.g., of the adults of Kirkaldyia (Tsuzuki et al., 1999). The larvae of H. acuminatus may similarly be able to recognize the smell of prey and are attracted by many species of prey, although some are unsuitable for them to complete their development and may thus serve only as supplementary food.

The results are also important for insect conservation. Predatory invertebrate populations are often limited by their food supply (Lenski, 1984; Pearson \& Knisley, 1985; Juliano, 1986) and understanding their trophic ecology can result in the development of more efficient conservation measures. Hydrophilus species are endangered taxa in many parts of the world, including, e.g., Great Britain (Beebee, 2007) and Japan (Ministry of the Environment, Government of Japan, 2012). While the larvae of Hydrophilus are carnivores, the adults are mainly herbivores or omnivores; thus, they need diverse ecosystems for their development. The habitats of freshwater species, including insects and other invertebrates, are increasingly threatened worldwide (Allan \& Flecker, 1993). Decrease in the numbers of suitable aquatic habitats due to the abandonment of rice paddies, water pollution, pesticide use and invasion by non-native species is causing great concern in Japan (Ministry of the Environment, Government of Japan, 2007; Nishihara et al., 2006). The result presented in this paper may help focus the conservation efforts on protecting species of Hydrophilus by maintaining appropriate habitats for them 
as the association between the occurrence of Hydrophilus species and the local snail fauna is largely overlooked and unknown.

ACKNOWLEDGEMENTS. We thank M. Hasegawa, M. Ito and A. Kobayashi (Toho University) for helping us with data analyses and procedures, Y. Minoshima (Hokkaido University) and M. Archangelsky for providing literature, J.N. Macabidang for her English suggestions and M. Fikáček, M. Schilthuizen, D. Boukal and anonymous reviewers for their constructive comments on the manuscript.

\section{REFERENCES}

Allan J.D. \& FleCKer A.S. 1993: Biodiversity conservation in running waters. - Bioscience 43: 32-43.

ARCHANGELSKY M. 1997: Studies on the biology, ecology, and systematics of the immature stages of New World Hydrophiloidea (Coleoptera: Staphyliniformia). — Bull. Ohio Biol. Surv. (N.S.) 12: $207 \mathrm{pp}$.

BALDUF W.V. 1935: The Bionomics of Entomophagous Coleoptera. E.W. Classey, Hampton, 200 pp.

BATZER D.P. \& WisSINGER S.A. 1996: Ecology of insect communities in nontidal wetlands. - Annu. Rev. Entomol. 41: 75-100.

BAY E. 1974: Predator-prey relationships among aquatic insects. - Annu. Rev. Entomol. 19: 441-453.

BeEBEe T.J.C. 2007: Population structure and its implications for conservation of the great silver beetle Hydrophilus piceus in Britain. - Freshw. Biol. 52: 2101-2111.

Berman E.H., Wright P. \& Mashke J.E. 2000: Biology of Agabus disintegratus (Crotch) (Coleoptera: Dytiscidae) in central Georgia with a description of its mature larva. - Georgia J. Sci. 58: 208-216.

Blunck H. 1923: Die Entwicklung des Dytiscus marginalis L. vom Ei bis zur Imago. 2. Teil. Die Metamorphose (B. Das Larven- und das Puppenleben). - Z. Wiss. Zool. 121: 117-391.

Bøwing A.G. \& Henriksen K.L. 1938: The developmental stages of the Danish Hydrophilidae. Videnskabelige Meddedelerser fra dansk naturhistorisk Forening i Kjobenhavn 102: 27-162.

Braun-Blanquet J. 1964: Pflanzensoziologie. 3. Aufl. Springer, Wien, xiv +865 pp. [Japanese translation 1971, by T. Suzuki (as Shokubutsu Shakaigaku), Asakura Shoten, Tokyo].

Chesson J. 1978: Measuring preference in selective predation. Ecology 59: 211-215.

Cobbaert D., Bayley S.E. \& Greter J.L. 2010: Effects of a top invertebrate predator (Dytiscus alaskanus; Coleoptera: Dytiscidae) on fishless pond ecosystems. - Hydrobiologia 644: 103-114.

Cummins K. 1973: Trophic relations of aquatic insects. - Annu. Rev. Entomol. 18: 183-206.

Formanowicz D.R. JR. 1987: Foraging tactics of Dytiscus verticalis larvae (Coleoptera: Dytiscidae): prey detection, reactive distance and predator. - J. Kans. Entomol. Soc. 60: 92-99.

Hansen M. 1999: World Catalogue of Insects 2: Hydrophiloidea (s. str.) (Coleoptera). Apollo Books, Amsterdam, 416 pp.

Hoso M., Asami T. \& Hori M. 2007: Right-handed snakes: convergent evolution of asymmetry for functional specialization. — Biol. Lett. 3: 169-173.

Hosor M. 1939: The life-history of Hydrous acuminatus Motschulsky. - Bot. Zool. 7: 1867-1874 [in Japanese].

INODA T. 2011: Preference of oviposition plant and hatchability of the diving beetle, Dytiscus sharpi (Coleoptera: Dytiscidae) in the laboratory. - Entomol. Sci. 14: 13-19.
INODA T. 2012: Predaceous diving beetle, Dytiscus sharpi sharpi (Coleoptera: Dytiscidae) larvae avoid cannibalism by recognizing prey. - Zool. Sci. 29: 547-552.

InODA T. \& Kamimura S. 2004: New open aquarium system to breed larvae of water beetles (Coleoptera: Dytiscidae). - Coleopt. Bull. 58: 37-43.

INODA T. \& KiTANO T. 2013: Mass breeding larvae of the critically endangered diving beetles Dytiscus sharpi sharpi and Dytiscus sharpi validus (Coleoptera: Dytiscidae). - Appl. Entomol. Zool. 48: 397-401.

InODa T., Hirata Y. \& Kamimura S. 2003: Asymmetric mandibles of water-scavenger larvae improve feeding effectiveness on right-handed snails. - Am. Nat. 67: 811-814.

Inoda T., Hasegawa M., Kamimura S. \& Hori M. 2009: Dietary program for rearing the larvae of a diving beetle, Dytiscus sharpi (Wehncke), in the laboratory (Coleoptera: Dytiscidae). —Coleopt. Bull. 63: 340-350.

JEFFRIES M. 1988: Individual vulnerability to predation: the effect of alternative prey types. - Freshw. Biol. 19: 49-56.

Johansson A. \& Nilsson A.N. 1992: Dytiscus latissimus and D. circumcinctus (Coleoptera, Dytiscidae) larvae as predators on three case-making caddis larvae. - Hydrobiologia 248: 201213.

JuLIANO S.A. 1986: Food limitation of reproduction and survival for populations of Brachinus (Coleoptera: Carabidae). - Ecology 67: 1036-1045.

KaWamura T. 1918: Freshwater Biology in Japan. Shokabo, Tokyo, 323 pp. [in Japanese].

KLEČKA J. \& BOUKAL D.S. 2012: Who eats whom in a pool? A comparative study of prey selectivity by predatory aquatic insects. - PLoS ONE 7(6): e37741.

Krebs C.J. 1989: Ecological Methodology. Harper Collins, New York, $654 \mathrm{pp}$.

LENSKI R.E. 1984: Food limitation and competition: a field experiment with two Carabus species. - J. Anim. Ecol. 53: 203-216.

LundKvist E., Landin J., Jackson M. \& Svensson C. 2003: Diving beetles (Dytiscidae) as predators of mosquito larvae (Culicidae) in field experiments and in laboratory tests of prey preference. - Bull. Entomol. Res. 93: 219-226.

Miall L.C. 1895: Aquatic Beetles: The Great Water-Beetle (Hydrophilus). The Natural History of Aquatic Insects, Macmillan, London, 61-87 pp.

Ministry of the EnVIronment, Government of JAPAN 2007: Red List of Japan. [in Japanese].

Ministry of the EnVIronment, Government of JAPAN 2012: Red List of Japan. [in Japanese].

Minoshima Y. \& HaYAshi M. 2011: Larval morphology of the Japanese species of the tribes Acidocerini, Hydrobiusini and Hydrophilini (Coleoptera: Hydrophilidae). - Acta Entomol. Mus. Nat. Pragae (Suppl.) 51: 118 pp.

Mori M. \& KitaYAma A. 2002: Dytiscoidea of Japan. Revised ed. Bun-ichi Sogo Shuppan, Tokyo, 217 pp. [in Japanese].

Mori A. \& OHBA S. 2004: Field observations of predation on snakes by the giant water bug. - Bull. Herpetol. Soc. Japan 2004: 78-81 [in Japanese].

Nakabo T. 2000: Fishes of Japan with Pictorial Keys to the Species. 2nd ed. Tokai University Press, Kanagawa, 2428 pp. [in Japanese].

NG P.K.L. \& TAN L.W.H. 1985: Right handedness in heterochelous calappoid and xanthoid crabs - suggestion for a functional advantage. - Crustaceana 49: 98-100.

Nishinara S., Karube H. \& Washitani I. 2006: Status and conservation of diving beetles inhabiting rice paddies. - Jpn. J. Conserv. Ecol. 11: 143-157 [in Japanese]. 
Pearson D.L. \& Knisley C.B. 1985: Evidence for food as a limiting resource in the life cycle of tiger beetles (Coleoptera: Cicindelidae). - Oikos 45: 161-168.

R Development Core Team 2013: R: A Language and Environment for Statistical Computing. R Foundation for Statistical Computing, Vienna, Austria. Available at http://www.R-project.org

RYAN T.A. 1960: Significance tests for multiple comparison of proportions, variances, and other statistics. - Psychol. Bull. 57: $318-328$.

ShigemiYa Y. 2003: Does the handedness of the pebble crab Eriphia smithii influence its attack success on two dextral snail species? - J. Zool. 260: 259-265.

Shoup J.B. 1968: Shell opening by crabs of the genus Calappa. Science 160: 887-888.

SHORT A.E.Z. \& FIKÁČEK M. 2011: World catalogue of the Hydrophiloidea (Coleoptera): additions and corrections II (20062010). — Acta Entomol. Mus. Nat. Pragae 51: 83-122.

Short A.E.Z. \& Hebauer F. 2006: World catalogue of Hydrophiloidea - additions and corrections, 1 (1999-2005) (Coleoptera). - Koleopt. Rundsch. 76: 315-359.

SNYDER R. \& SNYDER R.A. 1969: A comparative study of mollusc predation by limpkins, everglade kites, and boat-tailed grackles. - The Living Bird 8: 177-223.
Tsuda M. 1983: Aquatic Entomology. 7th ed. Hokyryukan, Tokyo, 166 pp. [in Japanese].

Tsuzuki Y., Taniwaki A. \& Inoda T. 1999: The Perfect Manuals for Breeding of Aquatic Insects. Data House, Tokyo, 223 pp. [in Japanese].

TuRner A.M. \& Chislock M.F. 2007: Dragonfly predators influence biomass and density of pond snails. - Oecologia 153: 407-415.

Ueno M. 1973: Kawamura Nihon Tansui Seibutsugaku. [Freshwater Biology of Japan.] Hokuryukan, Tokyo, 760 pp. [in Japanese].

Uchiyama R., Numata K., Maeda N. \& Seki S. 2002: A Photograph Guide; Amphibians and Reptiles in Japan. Heibonsha, Tokyo, 317 pp. [in Japanese].

VERMEIJ G.J. 1975: Evolution and distribution of left-handed and planispiral coiling in snails. - Nature 254: 419-420.

WeSENBERG-Lund C. 1943: Biologie der Susswasserinsekten. Nordisk Forlag, Copenhagen, 682 pp.

WILSON C.B. 1923: Life history of the scavenger water beetle, Hydrous (Hydrophilus) triangularis, and its economic relation to fish breeding. - Bull. U.S. Bur. Fish. 39: 9-38.

Received August 6, 2012; revised and accepted October 2, 2014 Prepublished online November 11, 2014 